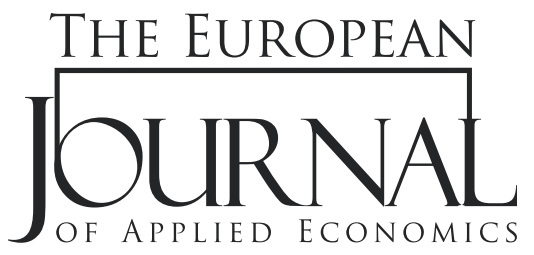

\title{
THE VULNERABLE FINANCIAL ISSUE: CAPITAL FLIGHT IN INDONESIA
}

\author{
Muhammad Basorudin*, R. Dwi Harwin Kusmaryo, Sri Hartini Rachmad, Gantjang Amannullah, \\ Serly Rachmadani Hamid
}

Badan Pusat Statistik - Statistics Indonesia, Jakarta,

Republic of Indonesia

\begin{abstract}
:
Indonesia is a developing country with a high demand for capital from both domestic and international sources. However, international capital flows are needed the most. For non-Western countries, especially Indonesia, capital flight is an unfavourable financial problem. This research aims to summarise capital flight from Indonesia and analyse the impact of macroeconomic and non-macroeconomic determinants through capital flight. Macroeconomic determinants include budget deficits, economic growth, inflation rates, and exchange rates. Nonmacroeconomic determinants are the degree of trade openness, interest rate differences, and dummy ratings. The data comes from the Bank of Indonesia, OECD, Moody's, and BPS-Statistics Indonesia. The coverage of this research is the Indonesian quarter from 2010 to 2018. This period complies with the latest procedures of the sixth edition of the Balance of Payments Manual (BPM 6). In this research, the measurement of the capital flight is the World Bank's residual method, trade misinvoicing method, and combined method. This research finds that, compared with other economics, non-macroeconomics is the most influential determinant of capital flight from Indonesia.
\end{abstract}

\section{Article info:}

Received: Jun 8, 2020

Correction: August 5, 2020

Accepted: December 11, 2020

\section{Keywords:}

capital flight, combined method, non-macroeconomics, Indonesia.

\section{INTRODUCTION}

After winning the 2019 presidential election, President Jokowi made a breakthrough in the National Development Plan (RPJMN) for 2020-2024. He will move Jakarta, the capital of Indonesia, to the island of Borneo. This policy will require a large budget, and make investors interested in investing their assets in Indonesia. He also built a track for the MotoGP event in Mandalika, a special economic zone in West Nusa Tenggara, from 2021-2023. The project will attract more investors from all over the world. 
In order to obtain large amounts of investment from all over the world, the Jokowi government has simplified investment regulations to create a business climate in Indonesia that is simpler than ever. The BKPM Investment Coordination Committee has developed a "one-stop service" system aimed at coordinating the permits and approvals of various ministries and commissions. This service is composed of 22 ministries and lasts 3 hours. Thanks to this innovation, Indonesia's Ease of Doing Business (EoDB) has risen from $114^{\text {th }}$ (2014) to $72^{\text {nd }}(2018)$ among 190 countries/regions.

Unfortunately, Indonesia recently lost its capital. Due to the social problems of the opposition, many capitalists or investors are moving/have moved their assets abroad. Several ministers were involved in corruption and criminal scandals during the previous government. This situation worsened the political situation. Thus, many investors continuously and abnormally invest funds from Indonesia in foreign countries. This situation is called "capital flight".

Capital flight is also classified as illegal capital flow. According to the 2017 Global Financial Integrity (GFI) report, Indonesia's illicit capital inflows are huge, amounting to USD 271.65 billion between 2005 and 2014.

At the moment, Indonesia and 209 other countries are facing the same problem: the COVID-19 pandemic. As of April 9, 2020, Indonesia had confirmed as many as 3,293 COVID-19 cases. The Asian Development Bank (ADB) predicts that, due to COVID-19, Indonesia's economy will grow by $2.5 \%$ in 2020. From an investment perspective, the lack of clear emergency measures will expose the business world and investors to unprecedented uncertainty. The market crash shows that the investment risk here has increased.

Now, due to the COVID-19 pandemic, foreign investors have recently dumped over USD 5 billion in Indonesian stocks and bonds (Samboh, 2020). Since Indonesia's business and investment environment is not good enough, this poor situation may cause capital flight to increase rapidly. The Indonesian government must foresee the negative impact of COVID-19 on the investment environment.

In an emerging country like Indonesia, capital movements play a key role in economic activity. The international flow of capital leads to the expansion of business activities, changes in economic structure, economic growth, the balance of payments, employability, economic stability in some countries, and the enhancement of competitiveness and the creation of globally competitive products (Sovran \& Hadzic, 2016). If a country has financial problems, such as capital flight, this may reflect a vote of no confidence in Indonesian assets. Ultimately, Indonesia's economy will be disrupted.

Capital flight will bring some adverse effects, such as reduced income and a decline in the ability of banks to create funds for investment projects. Most importantly, capital flight contributes to the income from non-Western countries to Western countries (Henry, 2013). In addition, capital flight greatly decreases private investment, but does not affect public investment (Yalta, 2010). Based on previous explanations, the purpose of this research is to summarise the investment potential of Indonesia in the short-term and long-term. In addition, this research also analyses the impact of macroeconomic and non-macroeconomic determinants of capital flight in Indonesia. 


\section{LITERATURE REVIEW}

\section{Previous Studies}

There are many determinants to capital flight. Some research found that the determinants of capital flight belonged to macroeconomics. An increase in budget deficit may also influence capital flight (Baek \& Yang, 2010; Mccaslin, 2013; Han et al., 2012).

On the other side, high inflation rates have a positive impact on capital flight (Ndikumana et al., 2014; Gouider and Nouira, 2014). At the same time, economic growth is a decisive factor for negative impacts, and therefore helps decrease capital flight (Gouider and Nouira, 2014; Cheung, Steinkamp and Westermann, 2016; Ndikumana et al., 2014). On the other hand, the exchange rate does not influence the capital flight of some non-Western countries (Geda \& Yimer, 2016; Adetiloye, 2012). Risks and returns (such as financial stability, domestic tax rates) and other macroeconomic determinants can also affect capital flight (Efobi \& Asongu, 2016).

The degree of trade openness is also a statistically significant variable for trade misinvoicing. Its coefficient is positive (Cheung, Steinkamp, \& Westermann, 2016; Mccaslin, 2013). This variable serves as a proxy for the existence and severity of trade misinvoicing. However, this currency is one of the most widely used determinants of capital flight.

In some ASEAN countries, there is a long-term equilibrium relationship between economic openness and GDP, as foreign direct investment, imports, and exports show the most important aspects of international economic integration, and the information is particularly important. There is a causal relationship between foreign direct investment, imports, exports, and GDP. In general, foreign direct investment, imports, and exports will significantly affect and lead to economic growth in the short-term and long-term (Vogiatzoglou \& Nguyen, 2016).

The results of econometric analysis based on a sample survey of 30 African countries from 1970 to 2015 also show that foreign direct investment flows are positively correlated with capital flight, which implies that the phenomenon of capital flight may be driven by foreign direct investment. However, there is no evidence that foreign direct investment will have spillover effects. The stock of foreign direct investment in the past does not affect capital flight. On the other hand, high natural resource rents are related to high capital flight, and the quality of the system cannot alleviate this connection (Ndikumana \& Sarr, 2019).

In some European countries (1996-2009), capital flight was determined by interest rate differentials and investors' perceptions of their economic conditions, as well as their access to funds that could be transferred overseas. Loans and capital inflows (Brada, Kutan and Vukšić, 2013).

Political risks and financial crises have a positive impact on capital flight. At the same time, external debt, foreign direct investment (FDI), and the stock market have a negative effect on capital flight (S.-L. Liew et al., 2016). Then again, political risk is also an important determinant for capital flight, especially corruption (Baek \& Yang, 2010). Deposit interest rates and inflation also have an eloquent effect on capital flight (Mccaslin, 2013). Debt changes, lagging inventory, and capital flight (lagging) have a significant and positive impact on capital flight; while inflation (lagging) and economic growth will have a negative impact (Ndikumana et al., 2014). 
In European countries such as Germany, traditional determinants of capital flight (such as the interest rate differential of guarantees) play only a limited role, while factors addressing the crisis, such as the uncertainty of economic policy, the collateral policy of the European Central Bank, and currency misalignment, are the driving factors causing this situation. Investors clearly evade safety (Cheung, Steinkamp, and Westermann, 2020).

In another part of the world, Latin America has experienced many interdependence problems, such as financial crises, unsustainable differences in power, sudden cessation of capital flows, capital flight, and the collapse of growth rates. Using data from eight Latin American countries during 1993-2015, capital flight is an interesting variable, showing a positive impact on sovereign bond spreads. Indeed, in order to increase debt repayment capabilities, Latin American countries are required to curb and prevent capital flight (Dachraoui, Smida, and Sebri, 2020).

In the long-term, only the debt stock, i.e., the difference between the nominal exchange rate and the interest rate (IR), has no significant impact on capital flight. In addition, in the long-term, political turmoil will have a negative impact on Nigeria's capital flight (Geda \& Yimer, 2016). Changes in inflation, Corruption Perception Index (CPI), debt, exchange rate and GDP have a positive impact on capital flight. However, changes in foreign direct investment have a negative impact on capital flight. Only inflation, CPI and exchange rate changes have eloquent consequences for capital flight (Wujung \& Mbella, 2016).

The ratio of capital flight (lagging), government debt ratio, economic growth, the real effective exchange rate (REER), Indonesia-US IR difference and virtual sovereign rating have a significant impact on capital flight (Basorudin, Kusmaryo and Rachmad, 2020). Looking at recent research, trade opening, political risks, economic growth and capital control have had negative impacts on capital flight. On the other hand, exchange rate regime, inflation rate and Strategic Economic Dialogue (SED) have a positive impact on capital flight (Cheung, Steinkamp, and Westermann, 2016).

In addition, some recent research shows that non-macroeconomic determinants lead to capital flight. Country risk, political turmoil, corruption and war are non-macroeconomic determinants that lead to capital flight (Geda \& Yimer, 2016; Baek \& Yang, 2010; Ndikumana, etc., 2014). Some research also have shown that economic crises, political risks and corruption are the main determinants of capital flight (Gunter, 2017; Cheung, Steinkamp and Westermann, 2016; Ndoricimpa, 2018; Efobi and Asongu, 2016).

Many kinds of research have shown that governance factors are one of the most influential determinants of capital flight. They are tax regulations, lower limits, much corruption, poor governance and abuse of political power (Ndikumana et al., 2014). However, these determinants are confusing and complicated to measure in Indonesia. Therefore, this research uses measurable, alternative non-macroeconomic determinants. The determining factor is the sovereign rating (Basorudin, Kusmaryo and Rachmad, 2020). Other research also used dummy variables as a another non-macroeconomic determinant of capital flight (Han et al., 2012).

Due to the complexity of capital flight, this research proposes non-macroeconomic determinants. This problem is the effect of the behaviour of the wealthy in the country. They want to flee their assets and wealth abroad for profit. They may stay away from investing their wealth simply because they are afraid of losing it. Both macroeconomic determinants and non-macroeconomic determinants are the main causes of capital flight. 


\section{Capital Flow Paradigm: Lucas Paradox}

The neoclassical theory believes that capital should flow from Western countries to non-Western countries (Qolbi \& Kurnia, 2015). However, the Lucas paradox criticizes this theory. According to Lucas' paradox, capital will not flow from the United States to India. Other research also found that capital flows from non-Western countries to Western countries. This situation indicates capital flight.

This contradictory issue with the neoclassical theory is called the "Lucas Paradox." The theoretical explanation of the Lucas paradox can be divided into two categories. They are fundamental differences and flaws in the international capital market (Alfaro, Sebnem and Volosovych, 2008). This is a further explanation of Lucas's paradox:

1) Fundamental Differences

a. Missing factors of production

One of the shortcomings of neoclassical theory is that it ignores the existence of other factors, such as human capital and land, which have a positive impact on the return of capital. This is why capital does not flow from Western countries to non-Western countries.

b.Government policy

Government policies may be another obstacle to capital flow and capital return.

c. Institutional structures

It is believed that, by protecting the property rights of investors from government influence, institutions will have an impact on investment decisions, thereby affecting the performance of the national economy.

2) International Capital Market Imperfections

a. Asymmetric information

Generally, the recipient of capital has more knowledge than the investor. If the investor does not have further information, the investor will tend to reduce investment (underinvestment). As a result, capital will not flow from Western countries to non-Western countries.

b. Sovereign risk

Sovereign risk is the perception non-residents have of domestic economic conditions (Ariefianto \& Soepomo, 2011). Normally, the sovereign risk of non-Western countries is high, so investors worry about no return on capital. As a result, capital will not flow to non-Western countries.

\section{METHODOLOGY}

\section{Measuring Capital Flight}

Calculating the amount of capital flight required calculation through the following approaches:

1. Residual Method

2. Dooley Method

3. Trade Misinvoicing

4. Hot Money Method

5. The Asset Method 
The above five measurement methods are divided into two categories: indirect measurement and direct measurement. The first three methods are indirect measurement, while the other methods are direct measurement. The residual method has been used in some recent research. In addition, since the measurement methods of capital flight include multiple types of personal capital flows, the residual method is the most appropriate measurement method in many situations (Wujung \& Mbella, 2016). Unfortunately, the measurement of the residual method ignores the flow of funds, just like debt forgiveness. The residual method developed by the World Bank is as follows:

$$
C F=\triangle E D+\triangle F I-S A D-\triangle F R
$$

$E D$ means foreign debt, FI means net foreign investment, CAD means current account deficit, and $\mathrm{R}$ means reserves. When the difference between the source of funds and the source of use is positive, it is called capital flight. Conversely, negative values are called inward capital flight.

In addition, some research points out that import and export activities are used to promote capital flight. For example, insufficient export invoices, excessive import invoices, and vice versa (Cheung, Steinkamp, and Westermann, 2016). In this research, the residual method and trade misinvoicing method is considered to be a feasible conceptual measure. These two measurements have been widely used in the literature.

On the other hand, direct measurement, especially hot money, has caused some criticism. Its measurement is based on errors and omissions. Errors and omissions consist of errors in compiled data, calculation errors, and unreported imports. In addition, the hot money method and other methods have also produced very inconsistent results (Mahmood, 2013). There is further criticism of direct measurement, especially asset methods. The metric assumes that national depositors have been reported, but this does not always happen in reality (Yalta, 2009).

Now, some research shows that import and export activities are used to promote capital flight (Cheung, Steinkamp and Westermann, 2016). Trade misinvoicing refers to illegal capital flows abroad, such as money laundering, smuggling, etc. (Yalta, 2009). In the trade misinvoicing valuation method, it is assumed that importers and exporters report that the value of imported goods is too high and the value of exported goods is too low (Yalta, 2009).

$$
E M=\sum_{i}^{n}\left[X W_{i, t}-X C_{i, t} \times(1+C I F)\right]
$$

Where $E M$ is export misinvoicing, $X W_{i, t}$ is Partner countries reported the value of import from Indonesia, and $X C_{i, t}$ is Indonesia's total export value to the country $i$.

$$
\begin{array}{r}
I M=\sum_{i}^{n}\left[M C_{i, t}-M W_{i, t} \times(1+C I F)\right] \\
T M=E M+I M
\end{array}
$$

On the other hand, $I M$ is an import invoicing, $M C_{i t}$ is Indonesia's total import value from the country $i, M W_{i, t}$ Partner countries reported value of export to Indonesia. And the export misinvoicing and import misinvoicing are called trade misinvoicing measurement of capital flight. In this research, the value of CIF is assumed to be 10 per cent commonly adopted in recent kinds of research on trade misinvoicing (Cheung, Steinkamp and Westermann, 2016). 
A positive sign on export misinvoicing indicates a net outflow (export under-invoicing), while a negative sign indicates net inflow. However, the positive sign on imports misinvoicing indicates a net outflow (importer over-invoicing), while a negative sign indicates net inflow. In this research, we expected the positive sign of exports and imports misinvoicing (Ndikumana et al., 2014).

The mechanism for trade misinvoicing is similar to the black market. Importers will be subject to higher tariffs to bring their capital "black money" to tax havens abroad. Similarly, exporters will take this "black money" abroad (Mahmood, 2013).

In this research, the World Bank residuals and trade misinvoicing methods are feasible conceptual measures. These two measurements have been widely used in the literature. Therefore, in this research, we will use well-known metrics, residual methods and trade invoice errors to measure capital flight. Then, we will also use a new measurement, the combined method. However, this method is a modification of the capital flight method in the kinds of research of Cheung, Steinkamp and Westermann (2016) and Wujung \& Mbella (2016).

\section{Data Sources}

These data are collected from the Bank Indonesia, BPS-Statistics Indonesia, OECD, Bloomberg and Moody's. In addition, the coverage of this research is the Indonesian quarter from 2010 to 2018. This period is suitable for the latest guidance of the balance of payments manual sixth edition program. The independent variables in this research are macroeconomic variables and non-macroeconomic variables.

They are the budget deficit as a percentage of GDP (budget ratio), economic growth, inflation rate, exchange rate, interest rate difference (US and Indonesia), trade openness and false sovereign ratings. In this research, we used modified new dummy variables. When Indonesia's sovereign rating value is lower than "Baa3", the virtual value is zero. This means that Indonesia's business climate is at a speculative level. When the rating is "Baa3" or higher, the dummy has a value of 1 . Therefore, the business climate is in a good state or investment level.

\section{Estimation Technique}

The estimation technique used in this research is ordinary least squares (OLS). Previous kinds of research have used this technique to estimate capital flight. Therefore, the regression model of capital flight is as follows:

$$
C F_{t}=\beta_{0}+\beta_{1} R D e f_{t}+\beta_{2} E c o_{t}+\beta_{3} \operatorname{Inf}_{t}+\beta_{4} E R_{t}+\beta_{5} I R \_D i f f+\beta_{6} \text { Open }_{t}+\beta_{7} D R_{t} \mu_{t}
$$

Where:

$$
\begin{array}{ll}
C F & =\text { Capital flight }(\mathrm{QtoQ}) \\
\text { RDef } & =\text { Budget deficit to GDP ratio (QtoQ) } \\
E c o & =\text { Economic growth (QtoQ) } \\
\text { Inf } & =\text { Inflation rate (QtoQ) } \\
E R & =\text { Exchange rate (QtoQ) } \\
\text { IR_Diff } & =\text { Interest rate differences (US-Indonesia) (QtoQ) }
\end{array}
$$




$$
\begin{array}{ll}
\text { Open } & =\text { Trade openness (QtoQ) } \\
D R & =\text { Dummy Rating (QtoQ) } \\
\mu & =\text { Error (QtoQ) }
\end{array}
$$

\section{RESULTS}

Figure 1: Capital flight (billion USD) in different measurements

a. World Bank Residual (WBR)

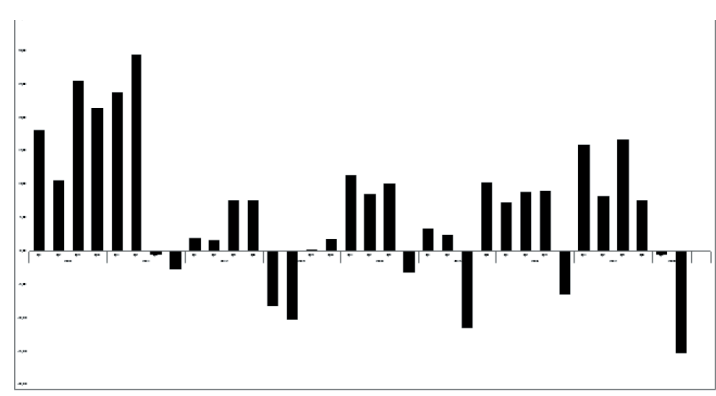

c. Combined Method (CM)

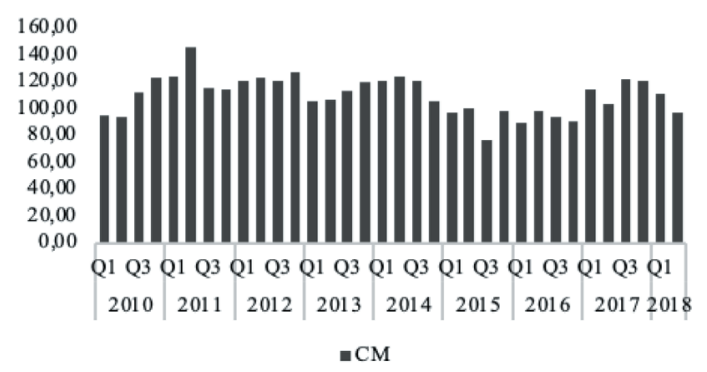

b. Trade Misinvoicing (TM)

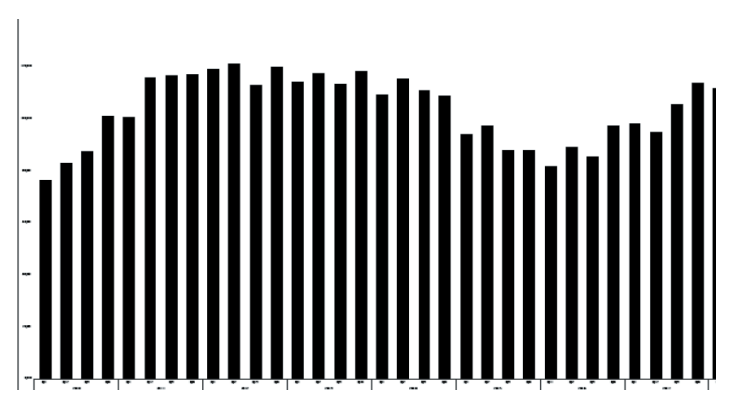

d. Combined Method Ratio to GDP (CMR)

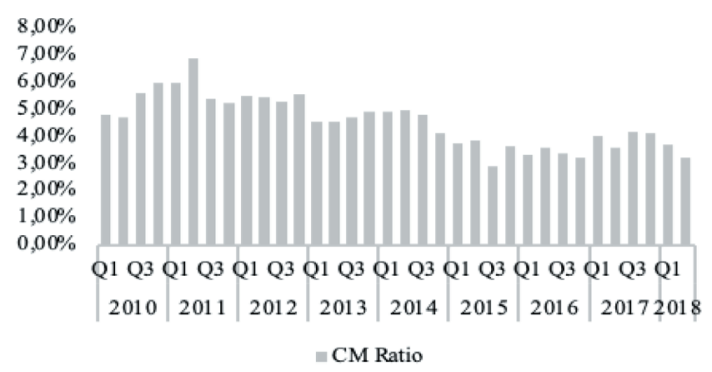

Source: Authors' calculation

Notes: The calculation of capital flight is based on the World Bank's residual (a), trade misinvoicing (b), and combined method (c) and combined method ratio to GDP (d). The combined method (CM) is the sum of the World Bank's residual and trade misinvoicing. ButHowever, the CM ratio is the total capital flight from CM to real GDP (with 2010 as the base year).

Figure 1 shows that WBRs do not match each other. Since 2011, there has been a capital reversal. However, other methods will not work. This difference is the result of Indonesia's reduction of trade restrictions and liberalization. This means that there is still a lot of illegal capital flows in trade. Many exporters and importers have benefited from trade. The measurement results may show different aspects. The World Bank's method is that of processing international transactions from the balance of payments statistics, while the TM method concentrates on false reporting of trade transactions.

In Figure 1, after the 2008 global economic crisis, the capital flight of Indonesia (WBR) increased rapidly. From the first quarter of 2010 to the second quarter of 2011, the scale of its capital outflow was larger than that in subsequent periods. The reason for this situation is the global economic downturn and domestic economic instability. 


\section{Determinants of Capital Flight}

Table 1 lists the influence of determinants of capital flight, including macroeconomic factors and non-macroeconomic factors. Generally, the exchange rate is statistically significant among the three methods. This result is different from previous kinds of research (Adetiloye, 2012). In that research, when the exchange rate decreases, Nigeria would have 60.22 units of capital flight (WBR) reduction.

Therefore, from this result, we recommend that Indonesian capital no longer portray the exchange rate as a reason for fleeing foreign capital. After the 2008 economic crisis, the IDR appreciated between 2009 and 2011. This situation shows that Indonesia's stabilization policy is firm in this crisis. As a result, only a few capitals have fled their assets abroad.

In addition, apart from the use of the CM method, the budget deficit (Rdef) does not statistically significantly affect capital flight. However, signs of budget deficits indicate a positive correlation with capital flight. This result is related to previous kinds of research (Han et al., 2012; Mccaslin, 2013). The increase in the budget deficit will increase capital flight from Hong Kong and European countries. This is caused by many price increases or corruption, and will increase investor risk aversion and deleveraging. As a result, there has been a large amount of capital flight.

Another Other research supports the revolving door relationship between capital flight and debt. More notably, the research found that, due to capital flight, countries with weak institutions are more likely to accumulate debt, which in turn generates financing needs (Cerra, Rishi, \& Saxena, 2008).

In 33 sub-Saharan African countries from 1970 to 2004, for every dollar of external loans provided to Africa during that period, approximately 60 cents were lost in the same year as capital flight. This finding indicates the existence of an extensive debt. Encouraging capital flight (Ndikumana and Boyce, 2011 ).

Therefore, fiscal policy plays an important role in defining the optimal relationship between expenditure and revenue in the budget. The government should use long-term financing if there is a deficit. In addition, public debt management is one of the main goals of every country, and an economy that lacks an appropriate strategy will face serious problems (Kalaš*, Andrašić, \& Pjanić, 2016).

Table 1: Comparison of Capital Flight Measurements

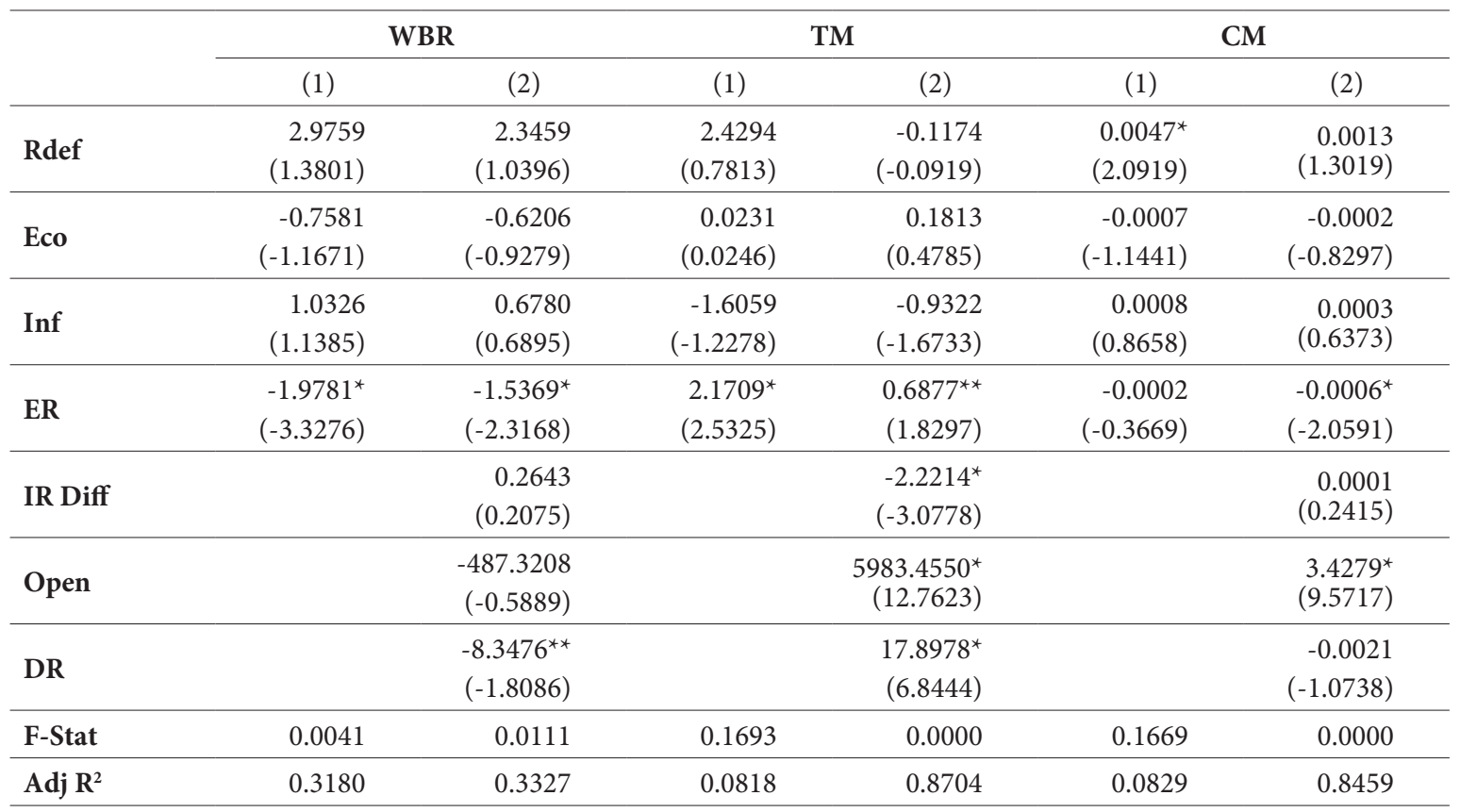

Notes: the estimated coefficients are statistically significant:* at $5 \%$ level, ** at $10 \%$ level. 
Economic growth will not have an impact or influence on capital flight. However, the signs of the coefficients are the same as in some previous kinds of research. If Indonesia's economic growth increases by one percentage point, it will reduce capital outflows to USD 620 million (WBR). This result also conforms to the Solow-Swan theory. In this theory, capital accumulation becomes an important determinant of economic growth (Mankiw, 2016). If there is a lack of capital, capital accumulation will decrease and Indonesia's economy will not be able to reach a stable state. Finally, Indonesia's economy becomes unstable, which can accelerate capital flight.

Then, foreign exchange reserves also play an important role in reducing capital flight. In the central bank's loss function, the greater the relative weight of the foreign exchange reserve target, the greater the range of attractiveness of stable equilibrium. In a stable equilibrium, the economy is less susceptible to capital flight (Kato, Proaño, and Semmler, 2018).

Since 2014, Indonesia's economic growth has stagnated at 5 per cent. It is evident that there are still many investors who get a lot of profit in Indonesia, but they do not reinvest their profit. Lewis explained that this phenomenon is caused by the fact that there is no reinvestment. The reinvestment in Indonesia is less profitable because the investors have to repay tax like a new investment. Besides, there are many overlapping regulations. Lewis's theory that this problem will cause capital flight from Indonesia. Finally, Indonesia's economy is quite difficult to achieve significant growth.

The results of this research are also related to the research of Gouder \& Nouira (2014) and Ndikumana et al. (2014). Both researchers found that every 1 percentage point increase in economic growth in nonWestern countries will reduce capital flight by 0.004 units, while 39 countries in Africa will decrease by 280 million US dollars.

At the same time, compared with other measurements, the TM method gives different results. The economic growth coefficient is positive in the TM method, but its coefficient is not statistically significant. This means that the calculation takes into account import and export factors, because economic growth also includes import and export value. Except for economic growth, the inflation rate is not statistically significant in any form of measurement (through capital flight). Except for the TM method, the sign of the inflation coefficient is positive.

Except for economic growth, the inflation rate is not statistically significant in any form of measurement, through capital flight. The coefficient of the inflation rate is related to the research hypothesis and previous research. Except for the TM method, it has positive signs. In the TM method, its sign is negative. This result is different because, economically speaking, inflation is not closely related to import and export activities. These activities are closely related to the exchange rate.

According to Table 1, a 1\% increase in the inflation rate will increase capital flight by US $\$ 1.04$ billion and US $\$ 680$ million (WBR). The Indonesian government has been controlling prices, especially basic demand prices, so Indonesia's inflation rate is relatively low. Since the economic crisis in 1998 and 2008, the government has been vigorously stabilizing prices. When the economic crisis happened in 2008, the rate of inflation in Indonesia had reached $11.06 \%$. Through macro-prudential policies to stabilize prices, the rate of inflation fell by $2.78 \%$. In addition, the rate of inflation in the past three years has reached the target (Bank Indonesia, 2018). This situation shows that Indonesia's price control is good enough. Therefore, investors or capitalists no longer believe that inflation is the main reason for their flight abroad. 
This result can also cope with previous research and research hypotheses. Almost all previous kinds of research found that the inflation rate does not influence capital flight (Ndikumana et al., 2014; Gouider \& Nouira, 2014). Then, a 1 percentage point increase in the inflation rate will increase capital flight by 0.003 units in non-Western countries, (Gouider \& Nouira, 2014). At the same time, in PIGS countries, the inflation rate increased by 1 percentage point, and capital flight would increase to USD 13.75 billion (Mccaslin, 2013).

Initially, researchers speculated that macroeconomic factors were the biggest factor affecting capital flight from Indonesia. However, according to Table 1, in these types of measures, capital flight through Indonesia, these factors are not statistically significant. In almost all measures, the exchange rate is the only important macroeconomic factor for capital flight. The budget deficit is only significant for the CM method.

After adding non-macroeconomic factors, certain non-macroeconomic factors have statistical significance in various measures of capital flight. However, macroeconomic factors still do not affect capital flight. We believe that non-macroeconomic factors are the biggest factor influencing capital flight from Indonesia.

Then, as can be seen from Table 1, inflation is not statistically significant. Many previous kinds of research have shown that inflation is one of the most influential factors for capital flight. In Indonesia, the inflation rate for ten years is very low. The government has also stabilized the normal level of consumer prices.

After the 2008 economic crisis, the inflation rate (YoY) dropped sharply from $11.06 \%$ to $2.78 \%$, and the inflation target was also between $4.5 \% \pm 1 \%$ (Bank Indonesia, 2018). Next, when the inflation rate reached the highest value of $4.35 \%$ (2013: third quarter). This shows that the inflation rate does not lead to capital flight.

Fictitious sovereign ratings similar to non-macroeconomic factors are also considered to be one of the determinants for capital flight. According to the results, sovereign ratings (virtual ratings) will not take effect through capital flight. Through capital flight, virtual ratings (DR) are statistically significant. It can reduce capital flight by USD 8.35 billion (WBR).

In other research, when the sovereign rating of Indonesia reaches investment level $(D=1)$, it may reduce the capital flight to 5.07 billion U.S. dollars. From this result, it can be seen that the influence of the sovereign level is more effective in reducing capital flight than other determinants (Basorudin, Kusmaryo and Rachmad, 2020).

This result is consistent with the theory of Lucas's paradox. In this paradigm, when sovereign risk is reduced, capital will flow to Indonesia. Since 2012, the sovereign rating has been upgraded from the speculative-grade level (Ba1) to the investment-grade level (Baa3). The example of Lucas Paradox indicates that the political system is the main factor influencing the economy.

In Indonesia, the political risk is high enough. There are still many worst cases such as corruption, crimes, instability, bad supervision, and others. These problems can lead the capital flow out from Indonesia rapidly. Although Indonesia is an emerging market country, the status of this political institution seems to have improved since 2012. The investment environment is at investment grade $(\mathrm{DR}=1)$. Therefore, there is some capital flight.

Through WBR, the coefficient of determination (R-squared) in this research is below 0.4. If non-macroeconomic factors are used as an explanatory variable, R-squared will increase sharply, and in various capital flight methods, $\mathrm{R}$-squared will reach 0.8 . Therefore, non-macroeconomic factors are factors that have recently had a greater impact on capital flight than macroeconomic factors. 
On the other side, the R-Squared of TM and CM are similar where, without non-macroeconomic determinants, their R-Squared is below 0.1. It means that the non-macroeconomics determinant may be one of the most influential factors of capital flight in Indonesia. Some previous kinds of research also yielded the same result with relatively small determinant coefficients (Wujung \& Mbella, 2016; Mccaslin, 2013; Shalizi, 2015; Gouider \& Nouira, 2014; Baek \& Yang, 2010; Ndikumana et al., 2014).

This relatively small coefficient of certainty does not mean that the factors used in this research are not suitable for measuring capital flight. This is because the research ignores other factors widely used in previous kinds of research, such as foreign debt and foreign direct investment (FDI). These two factors have exact statistical significance for capital flight, and can increase the coefficient of determination. This is because they are used to calculate the components of capital flight through the residual method (identity). If these variables are included in the formula, the result will be unreliable.

In addition, in recent kinds of research, the other non-macroeconomic variables, such as political turmoil or system quality, economic risk and corruption, also have a significant impact on capital flight (Ndikumana et al., 2014; Geda \& Yimer, 2016; Baek \& Yang, 2010). At the same time, these factors are difficult to measure in Indonesia.

In another region, such as in Africa, capital flight is not always explained by capital flows, and vice versa. This is due to the influence of geography, economy and currency regions (Wujung \& Mbella, 2016). The problem of capital flight can be solved by adopting a variety of policies, such as removing the control of overlapping regulations, simplifying the business process of the entire region (EoDB), equalizing the tax rate on reinvestment to a maximum of zero, and real-time monitoring of business processes.

In the 37 African countries from 1996 to 2020, corruption control and institutional governance have had a negative impact on capital flight, while the impact of the rule of law is not significant. In summary, corruption control is the most effective governance weapon against capital flight (Asongu \& Nwachukwu, 2017).

On the other hand, in the seven countries of the Commonwealth of Independent States (1995-2005), the liberalization of the trade and financial sectors accelerated capital flight by making capital easier to transfer abroad. In the short-term, strengthening supervision rather than liberalization of the external sector seems more likely to combat capital flight (Brada, Kutan, and Vukšić, 2011). However, financial liberalization policies by themselves may not help reduce the capital flight of 21 emerging market economies from 1980 to 2004 (Yalta \& Yalta, 2012).

\section{DISCUSSION, CONCLUSION, AND RECOMMENDATIONS:}

\section{Discussion}

Due to non-macroeconomic factors, such as political issues, corruption and poor regulation, Indonesia's most influential capital flight problem exists. So it can explain why the business climate in Indonesia is still not good, especially the regulations on starting a business, enforcing the contracts and paying taxes. There are a lot of plans to enhance the business climate for reducing the capital flight in the short-term and long-term .

Fiji is a small developing country in the Asia-Pacific region. The government of Fiji needs to formulate policies that focus on the long-term security and a stable business and political environment. 
Some of these policies may include making the domestic business and investment environment more attractive, reforming preferential tax policies for foreign investment, retaining qualified and skilled talent, eliminating institutional deficiencies in the banking system, and effectively implementing banking and customs regulations related to the transfer of financial capital (Gani, 2016).

In the short term, the creative economy is a good opportunity for Indonesia to reduce its capital flight. Indonesia is one of the largest creative economies in the world. In addition, Indonesia is also developing a digital economy for its economic future. Thomas T. Lembong, head of the Investment Coordination Committee, said that the digital economy is a sector that saves the pace of international investment . Research by Google and Temasek predicts that, by 2025, Indonesia's digital economy will reach USD 130 billion U.S. dollars, and by 2019 it will reach USD 40 billion U.S. dollars, an average annual growth rate of $49 \%$.

In some African countries, both from an absolute and conditional perspective, countries with lower capital flight rates are catching up with countries with higher interest rates. Consistent with the intuition that stimulated the analysis of policy coordination, two inferences can be drawn: (i) Convergence means that it is feasible to adopt a common policy to combat capital flight, and (ii) Completely within a specified time frame ( $100 \%$ ) convergence reflects the implementation (or coordination) of feasible policies without distinguishing nationality or region (Asongu, Uduji and Okolo-Obasi, 2020). Domestic credit expansion and financial liberalization in some European countries are reducing capital. Some solutions for the exodus . Domestic credit has become an important source of financing for capital flight.

Paradoxically, financial liberalization promotes, rather than reduces, capital flight by reducing costs and increasing funds that can be transferred abroad (Brada, Kutan, and Vukšić, 2013). In some countries in Latin America, governments require various implementations. Strategies, from the establishment of effective judicial and political institutions to the control of macroeconomic factors to promote growth (Dachraoui, Smida and Sebri, 2020 ).

In addition, many policymakers seem to prefer domestic alternatives to cross-border mergers. We constructed a model in which cross-border mergers reduce the wages set by labour unions, domestic mergers have non-labour cost synergies, and policy evaluators care more about workers than capital owners. Restrictive cross-border mergers and acquisitions policies may be counterproductive, because they do not necessarily lead to domestic mergers and acquisitions, but capital flight (Lommerud, Meland, and Straume, 2011).

\section{Conclusion and Recommendation}

Regarding the theory of macroeconomics and empirical data evaluation, this research is a novelty of controversial economic theory. This research shows that macroeconomic variables are not the main cause of capital flight in Indonesia, but non-macroeconomic variables such as country risk, corruption, tax evasion and tax avoidance have become the main important factors in how the dynamics of capital flight in Indonesia are driven.

Statistics show that, when the inflation rate rises by one percentage point, variables such as economic growth, inflation rate and sovereign rating do not have a significant impact on capital flight. Capital flight will increase by USD $\$ 1.04$ billion and 6.7\% (WBR) respectively. The fictitious rating can save USD 8.34 billion U.S. dollars. 
The most important findings and future actions of policies can be put forward based on this research as follows: capital flight policy actions should consider both macroeconomic and non-macroeconomics, and at the same time be related to the specific problems of capital flight, in order to find the best contemporary solutions. The rResearchers also believe that the problem of capital flight can be solved by adopting a variety of policies, such as removing the control of overlapping regulations, simplifying the business process (EoDB) of the entire region, equalizing the tax rate of reinvestment to zero, and monitoring business processes in real-time.

\section{REFERENCES}

Adetiloye, K. A. (2012). Capital Flight Versus Domestic Investment in Developing Countries: An Empirical Analysis from Nigeria. International Journal of Economics and Finance, 4(2), 175-186. https://doi.org/10.5539/ ijef.v4n2p175

Alfaro, L., Sebnem, K.-O., \& Volosovych, V. (2008). Why Doesn't Capital Flow from Rich to Poor Countries? An Empirical Investigation. The Review of Economics and Statistics, 90(2), 347-368. Retrieved from: https:// jstor.org/stable/40043150

Asongu, S.A., \& Nwachukwu, J.C. (2017). Fighting Capital Flight in Africa: Evidence from Bundling and Unbundling Governance. Journal of Industry, Competition and Trade, 17, 305-323. https://doi.org/10.1007/s10842-016-0240-1

Asongu, S., Uduji, J. I., \& Okolo-Obasi, E. N. (2020). Fighting African Capital Flight: Trajectories, Dynamics and Tendencies. Financial Innovation, 6(14), 1-21. https://doi.org/10.1186/s40854-020-00179-0

Bank Indonesia. (2018). Tinjauan Kebijakan Moneter. Jakarta: Bank Indonesia.

Baek, S., \& Yang, D. Y. (2010). Institutional Quality, Capital Flight and Capital Flows. The Korean Economic Review, 26(1), 121-155. Retrieved from: http://www.kereview.or.kr/modules/repec/backIssue_view.html?sk=rp_ti tle\&sv $=$ Institutional + Quality\&vol $=26 \&$ num $=1 \& p=1 \&$ no $=433$

Basorudin, M., Kusmaryo, R. D. H., \& Rachmad, S. H. (2020). Preventing Capital Flight to Reach Lucrative Investment in Indonesia. Journal of Business Economics and Environmental Studies, 10(1), 29-36. https:// doi.org/10.13106/jbees.2020.vol10.no1.29

Brada, J.C., Kutan, A.M. \& Vukšić, G. (2011). The Costs of Moving Money Across Borders and The Volume of Capital Flight: The Case of Russia and other CIS Countries. Review of World Economics, 147, 717-744. https://doi.org/10.1007/s10290-011-0100-3

Brada, J. C., Kutan, A. M., \& Vukšić, G. (2013). Capital Flight in the Presence of Domestic Borrowing: Evidence from Eastern European Economies. World Development, 51, 32-46. https://doi.org/10.1016/j.worlddev.2013.05.007

Cerra, V., Rishi, M., \& Saxena, S. C. (2008). Robbing the Riches: Capital Flight, Institutions and Debt. The Journal of Development Studies, 44(8), 1190-1213. https://doi.org/10.1080/00220380802242453

Cheung, Y.-W., Steinkamp, S., \& Westermann, F. (2016). China’s Capital Flight: Pre- and Post-crisis Experiences. Journal of International Money and Finance, 66, 88-112. https://doi.org/10.1016/j.jimonfin.2015.12.009

Cheung, Y.-W., Steinkamp, S., \& Westermann, F. (2020). Capital flight to Germany: Two alternative measures. Journal of International Money and Finance, 102, 102095. https://doi.org/10.1016/j.jimonfin.2019.102095

Dachraoui, H., Smida, M., \& Sebri, M. (2020). Role of capital flight as a driver of sovereign bond spreads in Latin American countries. International Economics, 162, 15-33. https://doi.org/10.1016/j.inteco.2020.04.002

Efobi, U., \& Asongu, S. (2016). Terrorism and Capital Flight from Africa. International Economics, 148, 81-94. https://doi.org/10.1016/j.inteco.2016.06.004

Gani, A. (2016). Capital Flight from a Small Developing Asia Pacific Economy. Perspectives on Global Development and Technology, 15(3), 303-318. https://doi.org/10.1163/15691497-12341391 
Geda, A., \& Yimer, A. (2016). A Dynamic Optimization and ARDL Approach to Determinants of Capital Flight from Ethiopia: Size, Determinants and Effect on Growth and Poverty. In AAU-Department of Economics Working Papers. https://doi.org/10.13140/RG.2.1.1474.5204

Gouider, A., \& Nouira, R. (2014). Relationship Between The Misalignment of The Real Exchange Rate and Capital Flight in The Developing Countries. Theoretical and Applied Economics, 21(11), 121-140. Retrieved from: http://store.ectap.ro/articole/1039.pdf

Gunter, F. R. (2017). Corruption, Costs, and Family: Chinese capital flight, 1984-2014. China Economic Review, 43, 105-117. https://doi.org/10.1016/j.chieco.2017.01.010

Han, Y., Gan, C., Hu, B., \& Li, Z. (2012). Hong Kong Capital Flight: Determinants and Features. Investment Management and Financial Innovations, 9(3), 33-46. Retrieved from: https://businessperspectives.org/journals/investmentmanagement-and-financial-innovations/issue-88/hong-kong-capital-flight-determinants-and-features

Henry, A. W. (2013). Analysis of the Effects of Capital Flight on Economic Growth: Evidence from Nigerian Economy (1980-2011). European Journal of Business and Management, 5(17), 21-33. Retrieved from: https://iiste.org/Journals/index.php/EJBM/article/view/6616/6761

Kalaš , B., Andrašić, J., \& Pjanić, M. (2016). Aspect of Fiscal Consolidation: Evidence from Serbia. The European Journal of Applied Economics, 13(2), 21-29. https://doi.org/10.5937/ejae13-10653

Kato, M., Proaño, C. R., \& Semmler, W. (2018). Does international-reserves targeting decrease the vulnerability to capital flights? Research in International Business and Finance, 44, 64-75. https://doi.org/10.1016/j. ribaf.2017.06.001

Liew, S.-L., Mansor, A. M., \& Puah, C.-H. (2016). Macroeconomic Determinants of Capital Flight: An Empirical Study in Malaysia. International Business Management, 10(13), 2526-2534. https://doi.org/10.36478/ ibm.2016.2526.2534

Lommerud, K. E., Meland, F., \& Straume, O. R. (2011). Mergers and capital flight in unionised oligopolies: Is there scope for a "national champion" policy? International Review of Economics \& Finance, 20(2), 325-341. https://doi.org/10.1016/j.iref.2010.06.005

Mahmood, Z. (2013). Reverse Capital Flight to Pakistan: Analysis of Evidence. The Pakistan Development Review, 52(1), 1-15. https://doi.org/10.30541/v52i1pp.1-15

Mankiw, N. G. (2016). Macroeconomics (Ninth). New York: Worth Publishers.

Mccaslin, W. A. (2013). Capital Flight: An Empirical Study on P.I.G.S. Copenhagen Business School.

Ndikumana, L., \& Boyce, J. K. (2011). Capital Flight from Sub-Saharan Africa: Linkages with External Borrowing and Policy Options, International Review of Applied Economics, 25(2), 149-170. https://doi.org/10.1080 /02692171.2010.483468

Ndikumana, L., Boyce, J. K., \& Ndiaye, A. S. (2014). Capital Flight: Measurement and Drivers. PERI Working Paper, 363, 1-62. Retrieved from: https://www.peri.umass.edu/fileadmin/pdf/working_papers/working_papers_351-400/WP363.pdf

Ndikumana, L., \& Sarr, M. (2019). Capital flight, foreign direct investment and natural resources in Africa. Resources Policy, 63, 101427. https://doi.org/10.1016/j.resourpol.2019.101427

Ndoricimpa, A. (2018). Greed of The Elite; Capital Flight from a Fragile Country: Case of Burundi, Journal of Financial Crime, 25(2), 598-618. https://doi.org/10.1108/JFC-11-2016-0075

Qolbi, N., \& Kurnia, A. S. (2015). Intra ASEAN-5 Capital Flows: Do They Represent Neoclassical Belief or Lucas Paradox? Buletin Ekonomi Moneter Dan Perbankan, 18(2), 157-182. https://doi.org/10.21098/bemp.v18i2.521

Samboh, Esther. (2020). Economics of Partial Lockdown to Contain Spread of Coronavirus [The Jakarta Post]. Retrieved from: https://www.thejakartapost.com/academia/2020/03/19/economics-of-partial-lockdownto-contain-spread-of-coronavirus.html

Shalizi, C. (2015). Is R-squared Useless? | University of Virginia Library Research Data Services + Sciences. Retrieved July 30, 2018, from https://data.library.virginia.edu/is-r-squared-useless/ 
Sovran, S., \& Hadzic, M. (2016). Contemporary Forms of International Movement of Capital. The European Journal of Applied Economics, 13(2), 1-9. https://doi.org/10.5937/ejae13-10617

Vogiatzoglou, K., \& Nguyen, P. N. T. (2016). Economic Openness and Economic Growth: A Cointegration Analysis for Asean-5 Countries. The European Journal of Applied Economics, 13(2), 10-20. https://doi. org/10.5937/ejae13-11311

Wujung, V. A., \& Mbella, M. E. (2016). Capital Flight and Economic Development: The Experience of Cameroon. Economics, 5(5), 64-72. https://doi.org/10.11648/j.eco.20160505.11

Yalta, A. Y. (2009). Capital Flight: Conceptual and Methodological Issues. Hacettepe University Journal of Economics and Administrative Sciences, 27(1), 73-94. Retrieved from: https://dergipark.org.tr/en/pub/ huniibf/issue/29197/312623

Yalta, A. Y. (2010). Effect of Capital Flight on Investment: Evidence from Emerging Markets. Emerging Markets Finance and Trade, 46(6), 40-54. https://doi.org/10.2753/REE1540-496X460603

Yalta, A. Y., \& Yalta, A. T. (2012). Does Financial Liberalization Decrease Capital Flight? A Panel Causality Analysis. International Review of Economics \& Finance, 22(1), 92-100. https://doi.org/10.1016/j.iref.2011.09.003 


\section{OSETLJIVO FINANSIJSKO PITANJE: ODLIV KAPITALA IZ INDONEZIJE}

\section{Rezime:}

Indonezija je zemlja u razvoju sa velikom potražnjom za kapitalom kako iz domaćih, tako i iz međunarodnih izvora. Međutim, međunarodni tokovi kapitala su najpotrebniji. Za zemlje u razvoju, posebno za Indoneziju, odliv kapitala predstavlja ozbiljan finansijski problem. Ovo istraživanje ima za cilj analizu odliva kapitala iz Indonezije i procenu uticaja makroekonomskih i nemakroekonomskih odrednica. Makroekonomski faktori uključuju budžetski deficit, ekonomski rast, stopu inflacije i kurs. Nemakroekonomski faktori su stepen otvorenosti privrede, razlike u kamatnim stopama i veštački rejting. Podaci dolaze iz Indonezijske banke, Organizacije za ekonomsku saradnju i razvoj, Mudisa i BPS-Statističkog zavoda Indonezije. Ovim istraživanjem obuhvaćen je period od 2010. do 2018. Podaci su u skladu sa najnovijim procedurama šestog izdanja Priručnika za platni bilans (BPM 6). U ovom istraživanju, metode za merenje odliva kapitala su rezidualna metoda Svetske banke, metoda pogrešnog fakturisanja i kombinovana metoda. Ovo istraživanje otkriva da, u poređenju sa drugim ekonomijama, faktori koji nisu makroekonomske prirode su najuticajnija odrednica odliva kapitala iz Indonezije.

\section{Ključne reči:}

odliv kapitala, kombinovani metod, mikroekonomija, Indonezija. 